\title{
Disequilibrium of polyunsaturated fatty acids status and its dual effect in modulating adipose tissue development and functions
}

\author{
Didier F. Pisani ${ }^{1,2,3, \star}$, Ez-Zoubir Amri ${ }^{1,2,3}$ and Gérard Ailhaud ${ }^{1,2,3}$ \\ 1 Université Nice Sophia Antipolis, iBV, UMR 7277, 06100 Nice, France \\ 2 CNRS, iBV, UMR 7277, 06100 Nice, France \\ 3 Inserm, iBV, U1091, 06100 Nice, France
}

Received 7 January 2015 - Accepted 12 January 2015

\begin{abstract}
White adipocytes are storing energy under the form of triglycerides whereas brown adipocytes dissipate energy from triglycerides by producing heat. In rodents and possibly in humans both types of fat cells participate in the total energy balance. From a quantitative view point, a positive energy balance (energy intake > energy expenditure) is commonly regarded as a major factor contributing to obesity. Recent studies demonstrate that by altering rates of adipocyte differentiation and proliferation, differences in fatty acid composition of dietary fats may also contribute to adipose tissue development, in particular with respect to the relative intake of $\omega 6$ to $\omega 3$ poly-unsaturated fatty acids (PUFAs). The $\omega 6 / \omega 3$ ratio determines the availability of $\omega 6$-arachidonic acid (ARA) within adipose tissue and thus the level of various prostaglandins derived from the cyclooxygenase-mediated pathway. We had shown earlier that prostacyclin (Prostaglandin I2) stimulates fat cell differentiation and this effect could be reversed by $\omega 3$-PUFA supplementation. Moreover, we had assessed that under conditions of genome stability a Western-like fat diet rich in $\omega 6$-PUFA was sufficient to induce a gradual fat mass enhancement across generations. Recently, we have characterized a second effect of some ARA metabolites (prostaglandins E2 and F2 $\alpha$ ) which appear to inhibit the formation of brown adipocytes within white adipose tissue. Altogether, our results demonstrate that, in addition to favoring white adipose tissue formation, dietary excess of $\omega 6$-PUFA prevents the "browning" process to take place in white adipose tissue depots, and strongly suggest a favorable role of $\omega 3$-PUFA supplementation in preventing both processes.
\end{abstract}

Keywords: White adipocyte / brite/brown adipocyte / arachidonic acid / prostaglandin / obesity

Résumé - Double effet d'un déséquilibre du statut en acides gras polyinsaturés sur le développement et les fonctions du tissu adipeux. Les adipocytes blancs stockent l'énergie sous forme de triglycérides alors que les adipocytes bruns dissipent l'énergie issue de ces triglycérides en produisant de la chaleur. Chez les rongeurs, et certainement chez les humains, ces deux types d'adipocytes participent à l'équilibre énergétique global. D'un point de vue quantitatif, une balance énergétique positive (apports énergétiques > dépenses énergétiques) est généralement considérée comme un facteur important contribuant à l'obésité. Des études récentes démontrent que des différences de composition en acides gras des graisses alimentaires en particulier le ratio entre les acides gras polyinsaturés $\omega 6$ et $\omega 3$, contribuent au développement du tissu adipeux en altérant les niveaux de prolifération et de différenciation des adipocytes. Le ratio $\omega 6 / \omega 3$ détermine la disponibilité de l'acide arachidonique $\omega 6$ (ARA) au sein du tissu adipeux et ainsi le niveau des différentes prostaglandines dérivées de la voie métabolique contrôlée par les cyclooxygénases. Nous avons précédemment montré que la prostacycline (Prostaglandin I2) stimule la différenciation des adipocytes et que cet effet pouvait être inversé grâce à une supplémentation en acides gras polyinsaturés $\omega 3$. De plus, nous avons démontré que, dans une situation de stabilité génomique, un régime alimentaire occidental riche en acides gras polyinsaturés $\omega 6$ suffisait à induire une augmentation progressive de la masse grasse d'une génération à l'autre. Récemment, nous avons caractérisé un second effet de certains métabolites de l'acide arachidonique (prostaglandines E2 et F2 $\alpha$ ) qui est d'inhiber la formation des adipocytes bruns au sein du tissu adipeux blanc. Pris ensemble, ces résultats démontrent que, en plus de favoriser la formation du tissu adipeux blanc, la consommation excessive d'acides gras polyinsaturés $\omega 6$ réduit la mise en place

^ Correspondence: pisani@unice.fr 
du processus de «brunissage » dans les dépôts de tissus adipeux blancs. Enfin, cela suggère fortement un rôle favorable d'une supplémentation en acides gras $\omega 3$ pour prévenir les deux processus.

Mots clés : Adipocyte blanc / adipocyte brun/brite / acide arachidonique / prostaglandine / obésité

\section{Introduction}

The energy unbalance in animals and humans is due largely to substantial reduction in energy expenditure worsened by fat or carbohydrate overconsumption.

So far, high-fat diets are considered to be obesogenic in that they produce a consistent increase in white fat mass that is directly related to the content of the diet and duration of feeding. However, the contribution of dietary fats in front of an excess of energy intake in increasing body weight remains controversial, as no major change in the total amount of ingested fats has occurred in the last two decades (Troiano et al., 2000; Willett et al., 2002), raising the possibility of a qualitative issue. Indeed qualitative changes in the composition of dietary lipids have occurred in Western populations. More specifically the balance of polyunsaturated fatty acids (PUFAs) of n-6 series (linoleic acid, LA: 18:2 n-6) and n-3 series ( $\alpha$-linolenic acid, LNA: 18:3 n-3) and their major metabolites, respectively arachidonic acid (ARA, 20:4 n-6) and EPA (20:5 n-3) and DHA (22:6n-3), has led to substantial increases in the $\omega 6 / \omega 3$ (or $n-6 / n-3$ ) ratio. Both a high intake of $\omega 6$ linoleic acid and a very high $\omega 6 / \omega 3$ ratio have been implicated in the promotion of many diseases, including cardiovascular inflammatory and autoimmune diseases and cancer (Okuyama et al., 2007; Hibbeln et al., 2006; Simopoulos, 2003). Regarding fat mass, recent studies have shown that perinatal exposure of mice to a high $\omega 6$ PUFA diet results in a progressive accumulation of body fat across generations, in agreement with the fact that in humans, overweight and obesity have steadily increased in the last decades, and emerge earlier in life (Massiera et al., 2010).

More recently another qualitative issue with respect to PUFAs of the $\omega 6$ series has been reported, i.e. their inhibitory role in the browning process of white fat cells converted into energy-dissipating fat brite (brown-like, see below) cells which are postulated to play a role in controlling energy balance by lowering body weight.

Herein, we summarize from our own data the potential importance of the fatty acid composition of dietary fats as a factor that plays a dual role in adipose tissue development and functions. More specifically will be discussed the role of the well-characterized arachidonic acid metabolites derived from the cyclooxygenase (COX) pathway (Fig. 1), on one hand prostaglandin I2 (prostacyclin, PGI2) and prostaglandin E2 (PGE2) which favor the formation of energy storing white adipocytes and, on the other hand PGE2 and prostaglandin F2 $\alpha$ (PGF2 $\alpha$ ) which prevent the formation of energy-dissipating brown-like adipocytes within white adipose tissue (WAT). Of note arachidonic acid is highly metabolized in this tissue and originates from different sources within adipocytes, i.e. directly from the diet or indirectly from LA metabolism in liver as well as from (i) phospholipids of preadipocytes and adipocytes via phospholipase activities and (ii) endocannabinoids via fatty acid amide hydrolase and monoacylglycerol lipase activities (Fig. 1).

\section{Arachidonic acid, prostacyclin, PGE2 and white adipogenesis}

Under isolipidic isoenergetic conditions, pups from mice fed a LA-rich diet ( $\omega 6 / \omega 3$ ratio of 59$)$ were heavier at weaning and fat mass was increased compared with pups where inclusion of LNA in the diet was taking place $(\omega 6 / \omega 3$ ratio of 2$)$. In other words, inclusion of LNA in the isoenergetic diet rich in LA prevented the enhancement of fat mass and the difference in body weight was maintained into adulthood (Massiera et al., 2003). Importantly, recent studies have shown that perinatal exposure to a high $\omega 6$ PUFA diet results in a progressive accumulation of body fat across generations (Massiera et al., 2010). Importantly also, in the guinea pig, which is considered as the best animal model of human adipose tissue growth, increasing the LA/LNA ratio from 2:1 to 30:1 during the preweaning period also resulted in increased fat mass in adulthood (Pouteau et al., 2010; Castaneda-Gutierrez et al., 2011).

In search of an indirect contribution of LA in enhancing adipose tissue development, female mice fed a LA-rich diet exhibited higher ARA levels in their milk (70\%) compared with mice fed the more balanced LA/LNA diet. Moreover, the LA-rich diet decreased $\omega 3$ long-chain PUFA in mother's milk, thereby inducing an unbalanced ratio between ARA, EPA and DHA for suckling pups. Consistent with a role of ARA in adipose tissue development, a significant positive association between plasma ARA levels and human infant body weight at 4 months of age was reported, as well as between ARA levels of adipose tissue lipids and BMI in children of Cyprus and Crete (Savva et al., 2004; Jensen et al., 1997). These human data were supporting our in vitro studies which had shown earlier that, among long chain fatty acids, ARA was the main adipogenic component of fetal bovine serum required for adipocyte differentiation (termed adipogenesis) of cultured mouse white preadipocytes. We had also shown that ARA was acting through prostacyclin synthesis whereas the $\omega 3$ isomer of ARA as well as EPA and DHA not giving rise to prostacyclin were no more potent than saturated and monounsaturated fatty acids in stimulating weakly adipogenesis (Massiera et al., 2003). After secretion from preadipocytes, prostacyclin was found to be active externally via the prostacyclin receptor (IP) present at the cell surface of preadipocytes. ARA, acting through the IP/prostacyclin system, triggered cAMP production and activated the pro-adipogenic protein kinase A pathway (Aubert et al., 2000; Vassaux et al., 1992a) (Fig 2). In rodents, both ex vivo and in vivo exposure of white adipose tissue to carbaprostacyclin, a stable ligand of IP, was able to stimulate the formation of adipocytes (Saint-Marc et al., 2001). Similar results were obtained with human preadipocytes (Jia et al., 2012). Moreover, ARA and some of its metabolites generated through cyclooxygenase activities had been described as activators/ligands of peroxisome proliferator activated receptors (PPARs) which stimulate adipogenesis (Hihi et al., 2002; Jehl-Pietri et al., 2000). Thus ARA was a potent activator 


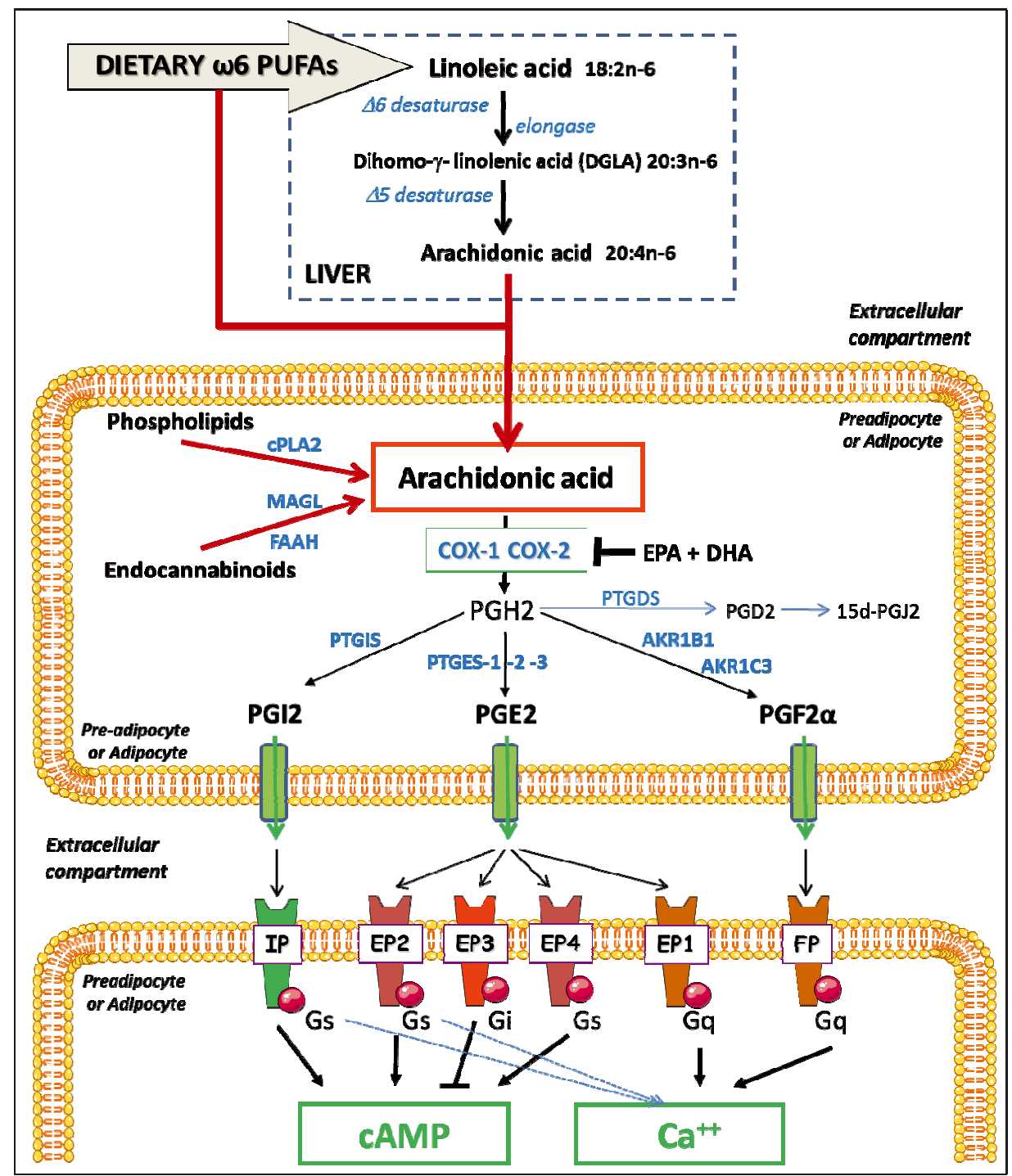

Fig. 1. Arachidonic acid synthesis from linoleic acid in hepatocytes and its metabolism in preadipocytes and adipocytes. Enzymes are shown in blue (cPLA2, cytosolic phospholipase A2; MAGL, monoacylglycerol lipase; FAAH, fatty acid amide hydrolase; COX, cyclooxygenase AKR1, acyl keto reductase 1). Sources of arachidonic acid are indicated with red arrows. Only the prostaglandins discussed in this review are displayed.

of adipogenesis that acts early through both cell-surface IP and later, like other long chainfatty acids, through nuclear PPARs (Fig. 2). To gain further insight into the contribution of prostacyclin signaling pathway in mouse adipose tissue development, wild-type mice and mice invalidated for IP $\left(i p^{-/-}\right)$ were used. In contrast to wild-type mice, pups from $i p^{-/-}$mice showed no gain in body weight or in fat mass when fed a LArich diet compared to the LA/LNA diet (Massiera et al., 2003). This striking observation demonstrated that the prostacyclin signaling pathway was a key event in increasing fat mass in response to excess of dietary LA. In other words, decreasing the dietary LA/LNA ratio decreased the potency of this proadipogenic pathway and thus prevented overweight.

The key question is whether a similar situation applies to humans. Controversial results have been obtained. High $\omega 6 / \omega 3$ ratio determined in umbilical cord blood phospholipids was associated with a high subscapular skin-fold thickness at 3 years of age taken as an index of child adiposity
(Donahue et al., 2011). In contrast, supplementation with EPA/DHA and recommendation to lower arachidonic acid intake during pregnancy and lactation did not show any effect on infant fat mass and fat distribution during the first year of life (Hauner et al., 2012). Ongoing time-consuming studies should help to solve this issue.

\section{Arachidonic acid, PGF2 $\alpha$ and inhibition of the browning process in white adipose tissue}

Brown adipose tissue (BAT) dissipates energy from triglycerides as heat (thermogenesis) by uncoupling the mitochondrial electron transport chain activity from ATP synthesis. This is due to the exclusive expression of the uncoupling protein (UCP)-1 in brown adipocyte mitochondria (Nedergaard et al., 2001; Frontini et al., 2010). In addition to the 


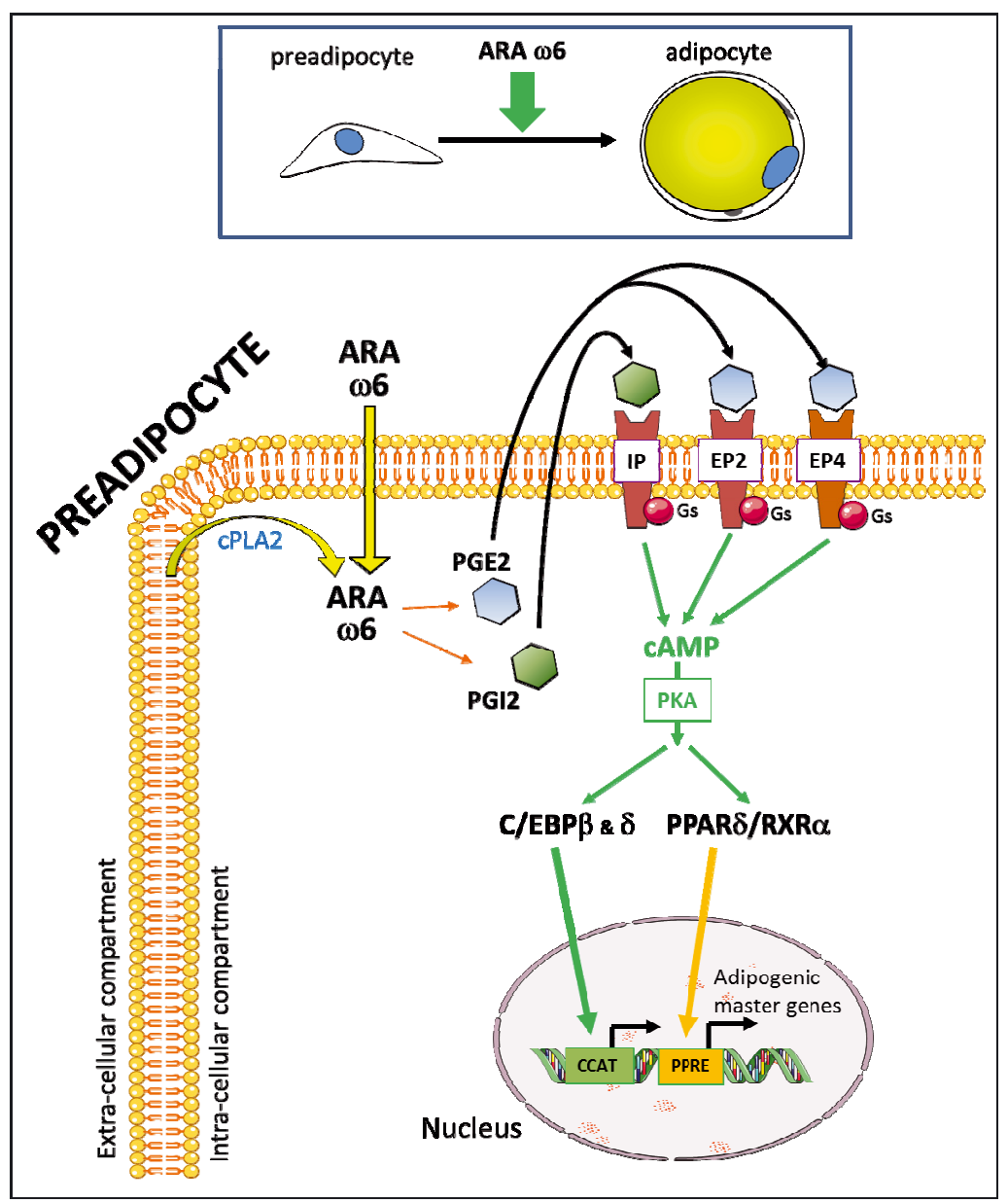

Fig. 2. Pathways involved in white adipocyte formation. (cPLA2, cytosolic phospholipase A2; PKA, protein kinase A; PPRE, PPAR response element; CEBP, CCAT/enhancer-binding protein; RXR, retinoid X receptor).

thermogenic adipocytes located in BAT - containing brown adipocytes - WAT contains inducible brown-like fat cells called "brown-in-white" ("brite") or "beige" adipocytes which are able to burn fat and carbohydrates via non-shivering thermogenesis (Petrovic et al., 2010; Ricquier et al., 2000; Barbatelli et al., 2010; Shabalina et al., 2013). Brite adipocytes appear to arise to a large part from the direct conversion of mature white adipocytes, and this mechanism is reversible (Barbatelli et al., 2010; Lee et al., 2014; Rosenwald et al., 2013). During the last decade, various laboratories have shown that healthy adult humans display islets of energy-dissipating thermogenic adipocytes of metabolic significance. Their activity, measured by $18 \mathrm{~F}$-fluorodeoxyglucose uptake, appears inversely proportional to WAT mass (Cypess et al., 2009; Nedergaard et al., 2007; Saito et al., 2009; van Marken Lichtenbelt et al., 2009; Virtanen et al., 2009), and these observations are in line with recent data which indicate that a lack of thermogenic adipocytes may be sufficient to cause obesity in mice and humans (Feldmann et al., 2009; van Marken Lichtenbelt et al., 2009). In addition, cold exposure led, in humans, to a decrease in body fat while recruiting brown adipocytes (Blondin et al., 2014; van der Lans et al., 2013; Yoneshiro et al., 2013). Altogether, these data explore new avenues and emphasize the occurrence of thermogenic adipocytes as novel important candidates in controlling body weight and the metabolism of lipids and carbohydrates through modulation of energy expenditure (Schottl et al., 2013). Importantly, brown adipocytes found in adult humans display a different molecular signature that the "true" brown adipocytes found in newborns but are rather reminiscent of the brite adipocytes described in rodents (Lidell et al., 2013). Therefore, investigations on the regulation of brite adipocyte recruitment and activation in humans are in demand from a nutritional view point, in particular to assess the possible impact of dietary $\omega 6$ PUFA and their metabolites.

Recently, we have demonstrated that among $\omega 6$ PUFAs, ARA inhibits late steps of brite adipocyte differentiation and maintains a white phenotype (Pisani et al., 2014). This observation has been described in vitro using a human cell model of white to brite adipocyte conversion (hMADS cells) and in mice using a nutritional approach. In the process of brite adipocyte formation from white hMADS adipocytes, ARA inhibited the expression of UCP1 and led to a decrease in their thermogenic capacity characterized by lower mitochondrial activity and basal oxygen consumption. The effect of ARA was mediated via cyclooxygenase activities leading to increased synthesis and release of PGE2 and PGF $2 \alpha$. Thorough analysis of the role of PGE2 and PGF2 $\alpha$ demonstrated that an oscillatory calcium 


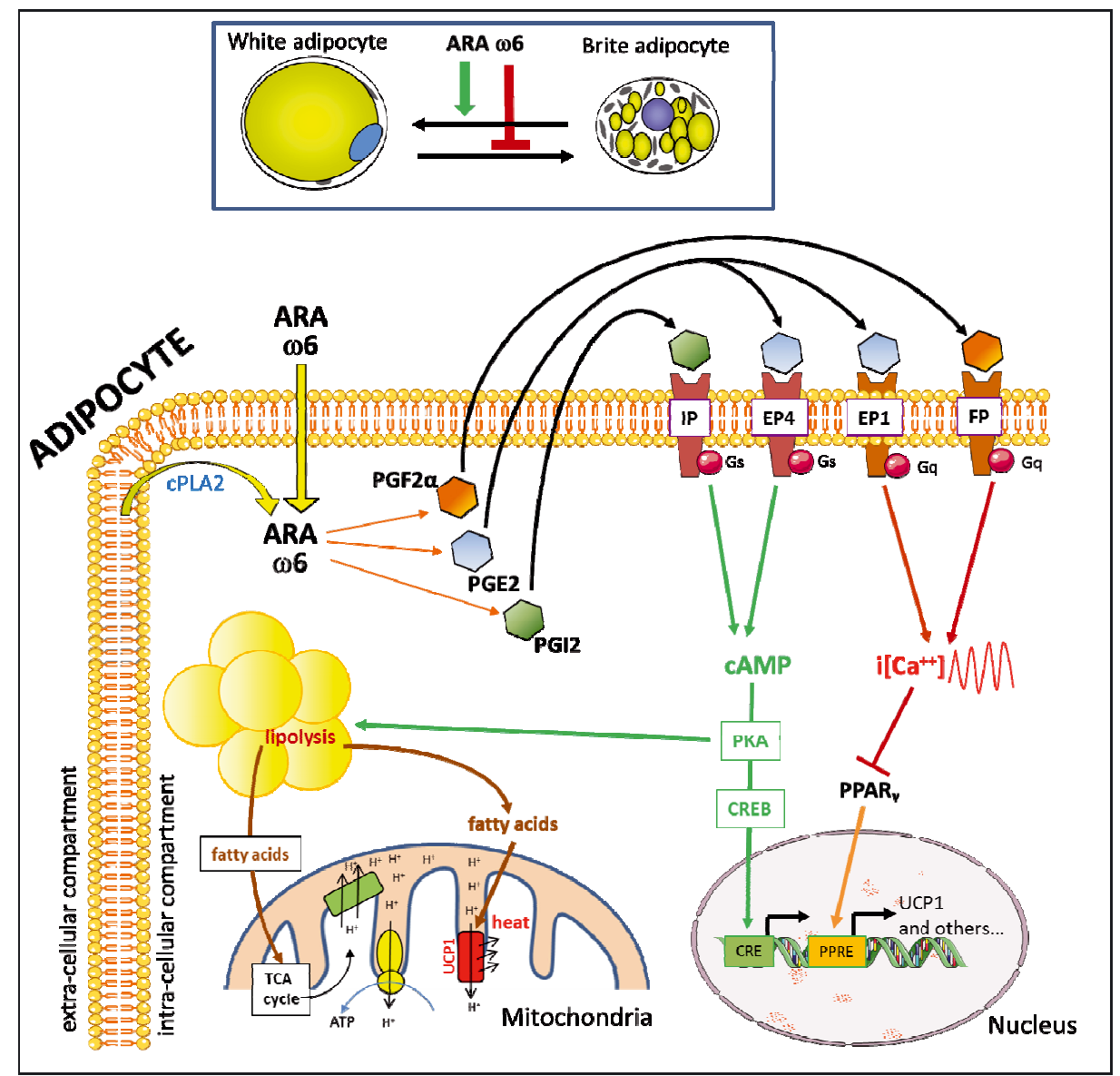

Fig. 3. Dual role of arachidonic acid in adipose tissue and the pathways involved in the white to brite adipocyte conversion (cPLA2, cytosolic phospholipase A2; PKA, protein kinase A; PPRE, PPAR response element; CRE, C-AMP Response Element; CREB, CRE-binding protein; TCA, tricarboxylic acid).

pathway, due respectively to EP1 and FP receptor activation, was responsible of impairing the browning process. The sustained $\mathrm{i}\left[\mathrm{Ca}^{++}\right]$oscillations led in turn to the inhibition of the expression of PPAR $\gamma$ target genes, including UCP1 gene and suggest a broader inhibitory effect of prostaglandin-mediated pathway via the modulation of PPAR $\gamma$ activity (Fig. 3).

As ARA is the precursor of numerous metabolites which trigger distinct signaling pathways, regulation of prostaglandin synthases should be crucial in inducing a given pathway. In this respect, it is worth noticing that ARA specifically inhibits expression of PTGIS (the enzyme responsible for prostacyclin synthesis) in hMADS adipocytes, thus favoring PGF2 $\alpha$ and PGE2 effects in hMADS cells at the expense of prostacyclin during the conversion of white to brite adipocyte.

In search for a direct involvement of ARA in vivo, female C57BL/6 mice were fed a standard diet (containing 5\% lipids) supplemented with $1.1 \%$ of arachidonic acid for 4 weeks. Mice were then treated with a $\beta 3$-adrenergic receptor agonist (CL316,243, 1mg/kg/day, daily injection for 1 week), known to mimic cold exposure and thus to increase in adipocytes UCP1 expression. Under isoenergetic isolipidic conditions, inclusion of ARA in the diet impaired brite adipocyte recruitment in the sub-cutaneous WAT compared to mice fed a standard diet, demonstrating the direct inhibitory effect of ARA
(Pisani et al., 2014). As expected, ARA supplementation increased prostaglandins and prostacyclin levels within the tissue. Of interest, the chronic stimulation of the $\beta 3$-adrenergic pathway in mice fed a standard or an ARA enriched diet induced a significant decrease in the levels of prostaglandins and prostacyclin but not that of PGF $2 \alpha$ which is maintained in ARA-supplemented fed mice, supporting the involvement of this prostaglandin in the ARA-mediated inhibitory effect on UCP1 gene expression.

Interestingly, in vivo, $\mathrm{COX}$ pathway has been shown to be crucial for the induction of brite adipocytes in 129Sv mice (a strain resistant to obesity due to a high content of brown and brite adipocytes) (Madsen et al., 2010; Vegiopoulos et al., 2010), but an opposite role of the same pathway has been recently described in C57BL/6 mice (a strain sensitive to high fat diets) (Fjaere et al., 2014). In this latter case, when mice were fed a high fat diet the inhibition of cyclooxygenase activities with indomethacin prevented weight gain, partly due to enhanced recruitment of brite adipocytes in the sub-cutaneous WAT. Our data obtained with C57BL/6 mice fed an ARAsupplemented diet in the absence of COX inhibitors are in agreement with this observation regarding the down-regulation of the browning process in WAT by $\omega 6$ poly-unsaturated fatty acids. 


\section{Dual role of PGE2 in adipocyte biology}

Extracellular PGE2 is known to bind to its wellcharacterized cognate receptors EP1, EP2, EP3 and EP4 with different affinities (Kringelholt et al., 2013) and was shown to trigger various signaling pathways as a function of the differentiation step (Fig. 1). EP2 and EP4 promote cAMP signaling, whereas, in an opposite way, EP3 is coupled to Gi protein able to inhibit adenylate cyclase activity. Last but not least, EP1 is a Gq coupled receptor allowing $\mathrm{Ca}^{++}$-mediated pathway.

In preadipocytes, PGE2 promoted cAMP signaling and triggered early adipogenesis via EP2 and EP4 (Vassaux et al., 1992b). In differentiated adipocytes, 16,16-dm-PGE2, a stable analog of PGE2, induced a dose-dependent inhibitory effect on UCP1 mRNA expression (Pisani et al., 2014). A maximal effect of 16,16-dm-PGE2 was found at a high concentration $(5 \mu \mathrm{M})$. Under these conditions, ARA-derived PGE2 bound to the low-affinity receptor EP1 and induced $\mathrm{i}\left[\mathrm{Ca}^{++}\right]$oscillations. Conversely, PGE2 was able to promote the white to brown/brite conversion at lower concentrations via the highaffinity EP4 coupled to the cAMP signaling pathway (Fig. 3).

\section{The $\omega 6 / \omega 3$ ratio as a critical factor to limit adverse effects}

Among lipid dietary factors, profound quantitative and qualitative changes have taken place in the last four decades in the Western industrialized world, particularly the rising intake of $\omega 6$ and the declining intake of $\omega 3$ PUFA by both humans and domesticated animals. As adipose tissue is the main peripheral target organ handling fatty acids several aspects of disequilibrated PUFA metabolism appear to conspire in stimulating white fat cell formation ( $\nearrow$ energy storage) and in inhibiting the brite adipocyte recruitment $(\searrow$ energy expenditure). The increased LA and ARA content of solid foods has been accompanied by a significant increase in the ARA/(DHA+EPA) ratio within adipose tissue, leading in turn to an increase in ARA metabolites, i.e. a stimulatory role of prostacyclin favoring white adipogenesis and an inhibitory role of PGF $2 \alpha$ preventing the browning process. Along with an increase in fat consumption and sedentarity, we propose that such disequilibration may represent an emerging risk factor which contributes to overweight and obesity as well as associated diseases in addition to the well-established positive energy balance. In other words, a decrease in LA or an increase in LNA/EPA+DHA intakes will allow a lower $\omega 6 \omega 3$ PUFA ratio and decreased the potency of this pro-adipogenic pathway and thus prevented overweight.

Acknowledgements. We thank all past and present colleagues from Gérard Ailhaud's and Ez-Zoubir Amri's team who were involved in these studies. Special thanks are due to Dr P. Guesnet for his contribution over the years. The works cited in this review were supported by CNRS, EU FP7 project DIABAT (HEALTH-F2-2011-278373), French Agence Nationale de la Recherche (ANR-05-PNRA-007 LIPADIP, ANR-10-BLAN-1105 miRBAT), Nutricia Research Foundation (2011-2025) and Société Française de Nutrition (2012 Research Prize).

Disclosure. The authors declare no conflict of interest.

\section{References}

Aubert J, Saint-Marc P, Belmonte N, Dani C, Negrel R, Ailhaud G. 2000. Prostacyclin IP receptor up-regulates the early expression of C/EBPbeta and C/EBPdelta in preadipose cells. Mol. Cell. Endocrinol. 160: 149-156.

Barbatelli G, Murano I, Madsen L, et al. 2010. The emergence of cold-induced brown adipocytes in mouse white fat depots is determined predominantly by white to brown adipocyte transdifferentiation. Am. J. Physiol. Endocrinol. Metab. 298: E1244-53.

Blondin DP, Labbe SM, Tingelstad HC, et al. 2014. Increased brown adipose tissue oxidative capacity in cold-acclimated humans. $J$. Clin. Endocrinol. Metab. 99: E438-46.

Castaneda-Gutierrez E, Pouteau E, Pescia G, Moulin J, Aprikian O, Mace K. 2011. The guinea pig as a model for metabolic programming of adiposity. Am. J. Clin. Nutr. 94: 1838S-1845S.

Cypess AM, Lehman S, Williams G, et al. 2009. Identification and importance of brown adipose tissue in adult humans. N. Engl. J. Med. 360: 1509-1517.

Donahue SM, Rifas-Shiman SL, Gold DR, Jouni ZE, Gillman MW, Oken E. 2011. Prenatal fatty acid status and child adiposity at age 3 y: results from a US pregnancy cohort. Am. J. Clin. Nutr. 93: 780-788.

Feldmann HM, Golozoubova V, Cannon B, Nedergaard J. 2009. UCP1 ablation induces obesity and abolishes diet-induced thermogenesis in mice exempt from thermal stress by living at thermoneutrality. Cell. Metab. 9: 203-209.

Fjaere E, Aune UL, Roen K, et al. 2014. Indomethacin Treatment Prevents High Fat Diet-induced Obesity and Insulin Resistance but Not Glucose Intolerance in C57BL/6J Mice. J. Biol. Chem. 289: 16032-16045.

Frontini A, Cinti S. 2010. Distribution and development of brown adipocytes in the murine and human adipose organ. Cell. Metab. 11: 253-256.

Hauner H, Much D, Vollhardt C, et al. 2012. Effect of reducing the n-6:n-3 long-chain PUFA ratio during pregnancy and lactation on infant adipose tissue growth within the first year of life: an openlabel randomized controlled trial. Am. J. Clin. Nutr. 95: 383-394.

Hibbeln JR, Nieminen LR, Blasbalg TL, Riggs JA, Lands WE. 2006. Healthy intakes of n-3 and n- 6 fatty acids: estimations considering worldwide diversity. Am. J. Clin. Nutr. 83: 1483S-1493S.

Hihi AK, Michalik L, Wahli W. 2002. PPARs: transcriptional effectors of fatty acids and their derivatives. Cell. Mol. Life Sci. 59: 790-798.

Jehl-Pietri C, Bastie C, Gillot I, Luquet S, Grimaldi PA. 2000. Peroxisome-proliferator-activated receptor delta mediates the effects of long-chain fatty acids on post-confluent cell proliferation. Biochem. J. 1: 93-98.

Jensen CL, Prager TC, Fraley JK, Chen H, Anderson RE, Heird WC. 1997. Effect of dietary linoleic/alpha-linolenic acid ratio on growth and visual function of term infants. J. Pediatr. 131: 200 209.

Jia B, Madsen L, Petersen RK, et al. 2012. Activation of protein kinase a and exchange protein directly activated by cAMP promotes adipocyte differentiation of human mesenchymal stem cells. PLoS One 7: e34114.

Kringelholt S, Simonsen U, Bek T. 2013. Dual effect of prostaglandins on isolated intraocular porcine ciliary arteries. Acta. Ophthalmol. 91: 498-504.

Lee YH, Petkova AP, Konkar AA, Granneman JG. 2014. Cellular origins of cold-induced brown adipocytes in adult mice. FASEB J.

Lidell ME, Betz MJ, Dahlqvist Leinhard O, et al. 2013. Evidence for two types of brown adipose tissue in humans. Nat. Med. 19: 631634. 
Madsen L, Pedersen LM, Lillefosse HH, et al. 2010. UCP1 induction during recruitment of brown adipocytes in white adipose tissue is dependent on cyclooxygenase activity. PLoS One 5: e11391.

Massiera F, Barbry P, Guesnet P, et al. 2010. A Western-like fat diet is sufficient to induce a gradual enhancement in fat mass over generations. J. Lipid Res. 51: 2352-2361.

Massiera F, Saint-Marc P, Seydoux J, et al. 2003. Arachidonic acid and prostacyclin signaling promote adipose tissue development: a human health concern? J. Lipid Res. 44: 271-279.

Nedergaard J, Bengtsson T, Cannon B. 2007. Unexpected evidence for active brown adipose tissue in adult humans. Am. J. Physiol. Endocrinol. Metab. 293: E444-E452.

Nedergaard J, Golozoubova V, Matthias A, Asadi A, Jacobsson A, Cannon B. 2001. UCP1: the only protein able to mediate adaptive non-shivering thermogenesis and metabolic inefficiency. Biochim. Biophys. Acta. 1504: 82-106.

Okuyama H, Ichikawa Y, Sun Y, Hamazaki T, Lands WE. 2007. Cancers common in the USA are stimulated by omega 6 fatty acids and large amounts of animal fats, but suppressed by omega 3 fatty acids and cholesterol. World Rev. Nutr. Diet. 96: 143-149.

Petrovic N, Walden TB, Shabalina IG, Timmons JA, Cannon B, Nedergaard J. 2010. Chronic peroxisome proliferator-activated receptor gamma (PPARgamma) activation of epididymally derived white adipocyte cultures reveals a population of thermogenically competent, UCP1-containing adipocytes molecularly distinct from classic brown adipocytes. J. Biol. Chem. 285: 71537164.

Pisani D, Ghandour R, Beranger G, et al. 2014. The $\omega 6$-fatty acid, Arachidonic acid, regulates the conversion of white to brite adipocyte through a prostaglandin/calcium mediated pathway. Mol. Metab. 3: 834-847.

Pouteau E, Aprikian O, Grenot C, et al. 2010. A low alpha-linolenic intake during early life increases adiposity in the adult guinea pig. Nutr. Metab. Lond. 7: 8.

Ricquier D, Miroux B, Larose M, Cassard-Doulcier AM, Bouillaud F. 2000. Endocrine regulation of uncoupling proteins and energy expenditure. Int. J. Obes. Relat. Metab. Disord. 24: S86-8.

Rosenwald M, Perdikari A, Rulicke T, Wolfrum C. 2013. Bidirectional interconversion of brite and white adipocytes. Nat. Cell. Biol. 15: 659-667.

Saint-Marc P, Kozak LP, Ailhaud G, Darimont C, Negrel R. 2001. Angiotensin II as a trophic factor of white adipose tissue: stimulation of adipose cell formation. Endocrinology 142: 487-492.
Saito M, Okamatsu-Ogura Y, Matsushita M, et al. 2009. High incidence of metabolically active brown adipose tissue in healthy adult humans: effects of cold exposure and adiposity. Diabetes 58: $1526-1531$.

Savva SC, Chadjigeorgiou C, Hatzis C, et al. 2004. Association of adipose tissue arachidonic acid content with BMI and overweight status in children from Cyprus and Crete. Br. J. Nutr. 91: 643649.

Schottl T, Klingenspor M. 2013. Boosting mitochondrial biogenesis in white adipocytes: A route towards improved insulin sensitivity? Mol. Metab. 2: 128-129.

Shabalina IG, Petrovic N, de Jong JM, Kalinovich AV, Cannon B, Nedergaard J. 2013. UCP1 in brite/beige adipose tissue mitochondria is functionally thermogenic. Cell. Rep. 5: 1196-1203.

Simopoulos AP. 2003. Importance of the ratio of omega-6/omega-3 essential fatty acids: evolutionary aspects. World Rev. Nutr. Diet. 92: 1-22.

Troiano RP, Briefel RR, Carroll MD, Bialostosky K. 2000. Energy and fat intakes of children and adolescents in the united states: data from the national health and nutrition examination surveys. Am. J. Clin. Nutr. 72: 1343S-1353S.

van der Lans AA, Hoeks J, Brans B, et al. 2013. Cold acclimation recruits human brown fat and increases nonshivering thermogenesis. J. Clin. Invest. 123: 3395-3403.

van Marken Lichtenbelt WD, Vanhommerig JW, Smulders NM, et al. 2009. Cold-activated brown adipose tissue in healthy men. $N$. Engl. J. Med. 360: 1500-1508.

Vassaux G, Gaillard D, Ailhaud G, Negrel R. 1992a. Prostacyclin is a specific effector of adipose cell differentiation. Its dual role as a cAMP- and Ca(2+)-elevating agent. J. Biol. Chem. 267: 1109211097.

Vassaux G, Gaillard D, Darimont C, Ailhaud G, Negrel R. 1992b. Differential response of preadipocytes and adipocytes to prostacyclin and prostaglandin E2: physiological implications. Endocrinology 131: 2393-2398.

Vegiopoulos A, Muller-Decker K, Strzoda D, et al. 2010. Cyclooxygenase- 2 controls energy homeostasis in mice by de novo recruitment of brown adipocytes. Science 328: 1158-1161.

Virtanen KA, Lidell ME, Orava J, et al. 2009. Functional brown adipose tissue in healthy adults. N. Engl. J. Med. 360: 1518-1525.

Willett WC, Leibel RL. 2002. Dietary fat is not a major determinant of body fat. Am. J. Med. 113: 47S-59S.

Yoneshiro T, Aita S, Matsushita M, et al. 2013. Recruited brown adipose tissue as an antiobesity agent in humans. J. Clin. Invest. 123: $3404-3408$

Cite this article as: Didier F. Pisani, Ez-Zoubir Amri, Gérard Ailhaud. Disequilibrium of polyunsaturated fatty acids status and its dual effect in modulating adipose tissue development and functions. OCL, 2015, 22(4) D405. 